\title{
Evolution, reproduction and autopoiesis
}

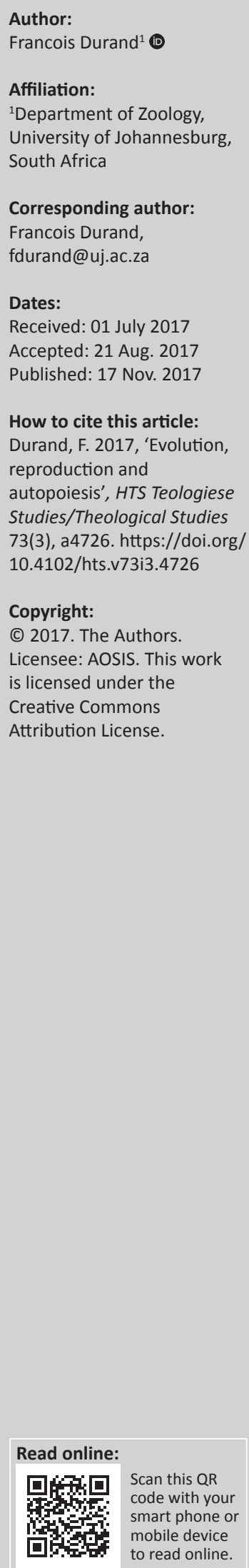

The term autopoiesis was coined to describe the regenerating and self-maintaining chemical systems of cells. The term has subsequently been applied to many different fields, including sociology, systems theory and information systems. This theory postulates that an autopoietic unity (cell, machine) is an organised network of processes that exists in a delimited space, which produces components which in turn continuously regenerate and create the network of processes that produced them. The Santiago Theory of Cognition grew from the Theory of Allopoiesis stating that all living systems are cognitive systems, and the process of living is a process of cognition. Cognition is the ability to adapt to a certain environment and cognition emerges because of a continuous bilateral interaction between the system and its environment. The resultant complexity seen in living systems is caused by this interaction between the system and its environment. Autopoiesis and cognition are however opposing concepts because cognition can only exist when the system is open and not closed as autopoiesis suggests. It is also difficult to see how autopoietic systems could originate if they are closed and how the continuous change which we see in evolution can be explained if life consists of autopoietic systems. It is postulated that cells and organisms are in fact open systems relating genetically to ancestors before them and their ever-changing descendants after them and the flow of molecules and energy through an ever-changing ecology.

\section{Introduction}

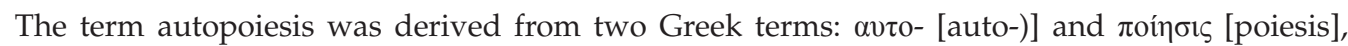
meaning self-creation or self-maintenance and is used to refer to a system which reproduces and maintains itself.

Humberto Maturana and Fransisco Varela, two Chilean biologists, coined this term to describe the regenerating and self-maintaining chemical systems of cells. The term has subsequently been applied to many different fields, including sociology, systems theory and information systems (Bača, Schatten \& Deranja 2007; Luhmann 2003).

Maturana and Varela (1973) explain in Autopoiesis and Cognition: the Realization of the Living that they created the term autopoiesis because they were unhappy with the term 'circular organisation' to describe living systems as unities and rather wanted a word that would emphasise the autonomy of the organisation of the living cell.

\section{Maturana recounts a conversation he had with a friend who wrote a paper on Don Quixote:}

It was in these circumstances ... in which he analyzed Don Quixote's dilemma of whether to follow the path of arms (praxis, action) or the path of letters (poeiesis, creation, production), I understood for the first time the power of the word "poeiesis" and invented the word that we needed: autopoiesis. This was a word without a history, a word that could directly mean what takes place in the dynamics of the autonomy proper to living systems. (Maturana \& Varela 1973)

\section{From cells to living systems}

Maturana and Varela (1973) describe an autopoietic unity (cell, machine) as an organised network of processes that exists in a delimited space, which produces components which in turn continuously regenerate and create the network of processes that produced them. They also stated that autopoietic systems produce more of their own complexity than the complexity produced by their environment. The core of their philosophy is that the cell reproduces itself and only itself (Zeleny 1981).

This definition was broadened to include higher organisms, living systems and even social systems by looking at the organisation of these systems with regard to the information and complexity contained in them. This gave rise to the Santiago Theory of Cognition (Maturana \& 
Varela 1978), which can be summarised in the following tenets: Living systems are cognitive systems, and the process of living is a process of cognition. Cognition is found in all organisms whether they have a nervous system or not.

Further elaborations of this theory include that cognition is the ability to adapt to a certain environment and that cognition emerges because of a continuous bilateral interaction between the system and its environment. The resultant complexity seen in living systems - including evolution - is caused by this interaction between the system and its environment.

The validity of the theories of autopoiesis and cognition could be challenged by the following questions:

- Are autopoiesis and cognition not opposing concepts?

- How did autopoietic systems originate if they are closed?

- Are cells and organisms not ultimately the result of the flow of energy through organic molecules that were inherited from ancestors or acquired from the environment - and are therefore not by definition open systems?

- If autopoietic systems are the product of the environment, should we not see cognition rather as a function of evolution and the ecology which brought about the organisms contained within it and produced by it? In other words, the whole (ecology, evolution) is cognitively bigger than the sum of the parts (cells, organisms).

\section{The suitability of the theory of autopoiesis to describe life}

In the original theory of autopoiesis, the authors emphasise the autonomy of the system and state that it can exist as an independent unit by even producing the components which constitute it and replicating itself. In the theory of cognition, the authors emphasise the interaction between the autopoietic system and its environment. The theory of cognition contradicts the theory of autopoiesis in these respects (Luisi 2003). Because the theory of cognition harmonises better with our understanding of the origin and evolution of life and the interrelationships between organisms, it calls into question the validity of the theory of autopoiesis as it was originally meant to describe the function of the cell and by extrapolation living organisms.

Maturana and Varela stated originally that autopoiesis was a prerequisite for life. They emphasised that 'autopoiesis is necessary and sufficient to characterize the organization of living systems' but later they synonymised this type of organisation with life when they stated that 'autopoiesis in the physical space is necessary and sufficient to characterize a system as a living system' (Maturana \& Varela 1980). Fleischacker (1988) went one step further by stating that as the living is autopoietic, logically everything which is autopoietic must also be living.

Varela, Maturana and Uribe (1974) introduced the term, allopoiesis, which is the opposite of autopoiesis. They state: in contradistinction, mechanistic systems whose organization are such that they do not produce the components and processes which realize them as unities and, hence, mechanistic systems in which the product of their operation is different from themselves, we call allopoietic. (pp. 188-189)

Zeleny (1977) summarises allopoiesis thus: 'Allopoietic systems are organizationally open. They produce something different from themselves'. It does not seem as if the authors realise that allopoiesis is more in line with the theory of cognition in that it is open to the environment and that it is the only way in which evolution can operate, namely, if an organism gives rise to something different from itself.

The theory of autopoiesis should be seen as a theoretical paradigm of life in the fashion of Aristotle's metaphysics rather than a unified and concise theory of life (Von Glaserfeld 1990; King 1993). Since its formulation to describe the function of the cell, autopoiesis has been adopted and adapted as a philosophical tool in a multitude of diverse disciplines (Mingers 1995). The wide appeal of this theory and its application in so many diverse fields attest to its philosophical value.

However, not everyone was equally taken with Maturana's philosophical approach when he and Varela expanded the theory of autopoiesis and cognition (Maturana 1975; 1987; Maturana \& Varela 1980). Maturana follows the traditional Aristotelian metaphysical approach by doing an inquiry into the structure of the world in order to understand reality. $\mathrm{He}$ also uses a hylomorphic approach as he describes the cell as a unity which can be defined by its organisation and structure, similar to Aristotle's form and matter (Dougall 1999).

There is a major difference in the philosophical approach of Aristotle and Maturana however with regard to the following questions: If an individual subject consists of many parts, why is it one thing and not many, and what is the reason for this unity? Aristotle answers this by means of his theory of hylomorphism, namely, that an individual subject is a unity of its form and matter. Maturana on the contrary sees that the structure of a unity is already potentially that unity while its organisation is already that unity in itself which makes the unity organisationally closed (Dougall 1999; 2000).

Mingers (1995) takes issue with Maturana's metaphysical claim that a unity such as a cell is a closed network of processes that has no reference to anything external to itself both in its constitution and its ontogeny. Mingers points out that Maturana's theories are self-contradictory and inconsistent. Mingers sees Maturana's self-referential theories as neoKantian radical constructivism (Dougall 2000; Mingers 1995).

In an attempt to promote the theory of autopoiesis as a theory of cellular life, Luisi (2003) states that autopoiesis is not an abstract theory, nor a theory of the origin of life, but rather a definition of minimal life aimed at forming a logical link with related notions, such as self-organisation, biological autonomy and an auto-referentiality. 


\section{The stuff of life}

A living organism is defined as a collection of molecules that forms a stable unit which exhibits all or most of the following physiological functions: organisation, metabolism, homeostasis, growth, reproduction, adaptation and response to stimuli. Although this definition may be true and seems to comply with the theory of autopoiesis, it does not address the relationship between the organism and its environment. The theory of cognition which describes emergence, the relationship between the environment and the cell and evolutionary adaptations, followed to address this logical shortcoming (Luisi 2003).

Homeostasis and metabolism have to do with the functioning of the chemical components within cells. Homeostasis is the regulation of the internal environment of a cell or organism to maintain stability. Metabolism is the conversion of chemicals (such as food, oxygen and water) and energy into cellular components and the decomposing of organic matter. Organisms need energy to maintain homeostasis and exhibit the other phenomena associated with life.

The response to stimuli has everything to do with the acquisition of life-sustaining molecules and energy. Adaptation and response to stimuli enable the organism to find molecules and energy in a continuing changing environment in order to sustain its life functions while avoiding becoming the food source of other organisms anxious to replenish their supply of molecules and energy. This acquisition of molecules is observed in all organisms while animals feed on other organisms, plants require molecules that are or were part of the atmosphere such as carbon dioxide, nitrogen, phosphorus and sulphur. Hydrogen is gained from water molecules through the process of photosynthesis. Animals utilise plants directly in the case of herbivores or indirectly in the case of carnivores eating herbivores. Molecules flow through the food web in this way.

The only reason why an organism feeds is to acquire molecules which they need to maintain their life processes of which the need to reproduce is the most important. Organisation, growth and reproduction are related functions again because they have to do with the replication or multiplication of molecules including DNA and ultimately cells and organisms.

\section{Lesser known facts about reproduction}

Life is simply the ability of DNA to replicate itself, and the cell which carries the DNA is the ultimate organism through which this is facilitated. Although cells have many functions, one should distinguish between cause and effect - the main reason for the existence of the cell is to house the DNA. All the other functions of the cell are secondary and relates to the maintenance, protection and replication of the DNA. The only reason for the existence of life is to beget life. The theory of autopoiesis specifically does not address the role of DNA and the origin of life (Luisi 2003) which could be seen as a shortcoming if it is not included in a definition of life.
Growth and reproduction are intimately related. Cells duplicate through binary fission. As the cell acquires more molecules, it enlarges, duplicates its DNA and then splits in two. There are different types of asexual reproduction, of which binary fission is the simplest and the most common way through which the majority of organisms including the archaea, bacteria and protists replicate. It is however not far different from normal growth that occurs in multicellular organisms where cells subdivide to form copies of themselves.

This is how embryos develop, injuries heal, growth occurs and cells are replaced. Multicellular organisms originated because of a small mutation which enabled newly formed cells to adhere to each other instead of splitting up. In this way, plants, fungi and animals originated from single-celled ancestors (Durand 2013). Several organisms such as slime mould can fluctuate between a single cell and a colonial state.

It is important to note however that liver cells make copies of liver cells and epithelial cells come from epithelial cells, but if one goes back to the original early embryo, different cells (blastomeres) will give rise to quite different and distinct organs with unique tissue types. The sponge may consist of aggregates of similar cells, but all animals more evolutionarily advanced than the sponge consist of tissues and organs. The embryo of multicellular animals beyond the grade of a sponge consist shortly after the original cleavage of cells that are not merely identical duplicates of the original zygote but distinctly different and fated to become different organs. In other words, in the early embryo, mitotic cleavage gives rise to cells different than the original which would fit the theory of allopoiesis.

Plants evolved from single-celled flagellated protists that contained chloroplasts similar to Chlamydomonas. The next step in the development of multicellularity occurred when clumps of these cells formed when dividing cells did not separate. This stage of evolution can be seen in Gonium which consists of a flat sphere of 4, 8, 12 or 16 cells depending on how many times the cells subdivide. The spherical Eudorina colonies on the contrary consist of 16,32 or 64 cells, each of which is similar to Chlamydomonas (see Figure 1). The hollow spherical colonies of Volvox, which consists of between 500 and 50000 Chlamydomonas-like cells, form the link between the first colonial algae and macroscopic green algae. Land plants evolved from green algae.

Over time, the flagella disappeared from the somatic (body) cells of macroscopic algae, but they reappeared in the gametes (sperm and egg cells) which are called zoogametes because of their ability to swim around in search of a mate. It is important to realise that the zoogametes resemble their ancestors in every way except for the fact that they are haploid. Algae also produce zoospores for asexual reproduction which resemble their ancestors even more in that they are diploid. These single-celled stages of multicellular organisms look and behave like their protist ancestors. They swim around, are sensitive to chemical signals, avoid predators and feed - just like normal protists, the only real difference being their 
genetic programming which allows them to give rise to multicellular organisms.

Spores are commonly used by plants and fungi to reproduce asexually. Spores are single diploid cells similar to body cells. The fern thallus and moss sporangia for instance grow from spores. Sexual reproduction differs from asexual reproduction in that it involves the fusion of two parental haploid cells to form the single-celled diploid zygote with a unique genome. Regardless of how many time fusion between two individuals' ova and sperm take place, the result will be different every time. Sexual reproduction occurs in order to create progeny with genomes that differ from that of their parents, and this phenomenon in itself is something completely opposite to the production of identical copies of itself. After the first embryonic cell (zygote) is formed, it will start to replicate through binary fission, just like spores do, and so the embryo is formed.

Animals evolved, like plants did, from flagellated cells. Choanoflagellate protists formed the first macroscopic multicellular animals. Proterospongia are microscopically small sponges consisting of tiny colonies formed by a few choanaflagellate cells. Choanoflagellate cells are the most important cell type found in sponges (See Figure 2). Sponges are considered to be some of the first macroscopic animals to have evolved.

All life starts as a single cell. Most life forms remain in the form of single cells and we know them as archaea, bacteria and protists. The archaea and bacteria also resemble the first organisms on earth while protists were the first single-celled eukaryotic organisms. Multicellular life forms such as plants, fungi and animals start off as single cells which are virtually identical to protists (King 2004).

The gametes of algae resemble their Chlamydomonas-like ancestors, the sperm of most plants and animals resemble flagellated protists while the sperm of nematodes resembles amoeba (see Figure 3). The ameboid sperm of nematodes may be out of the ordinary but when one considers that flagellated and ameboid protists are related and that many

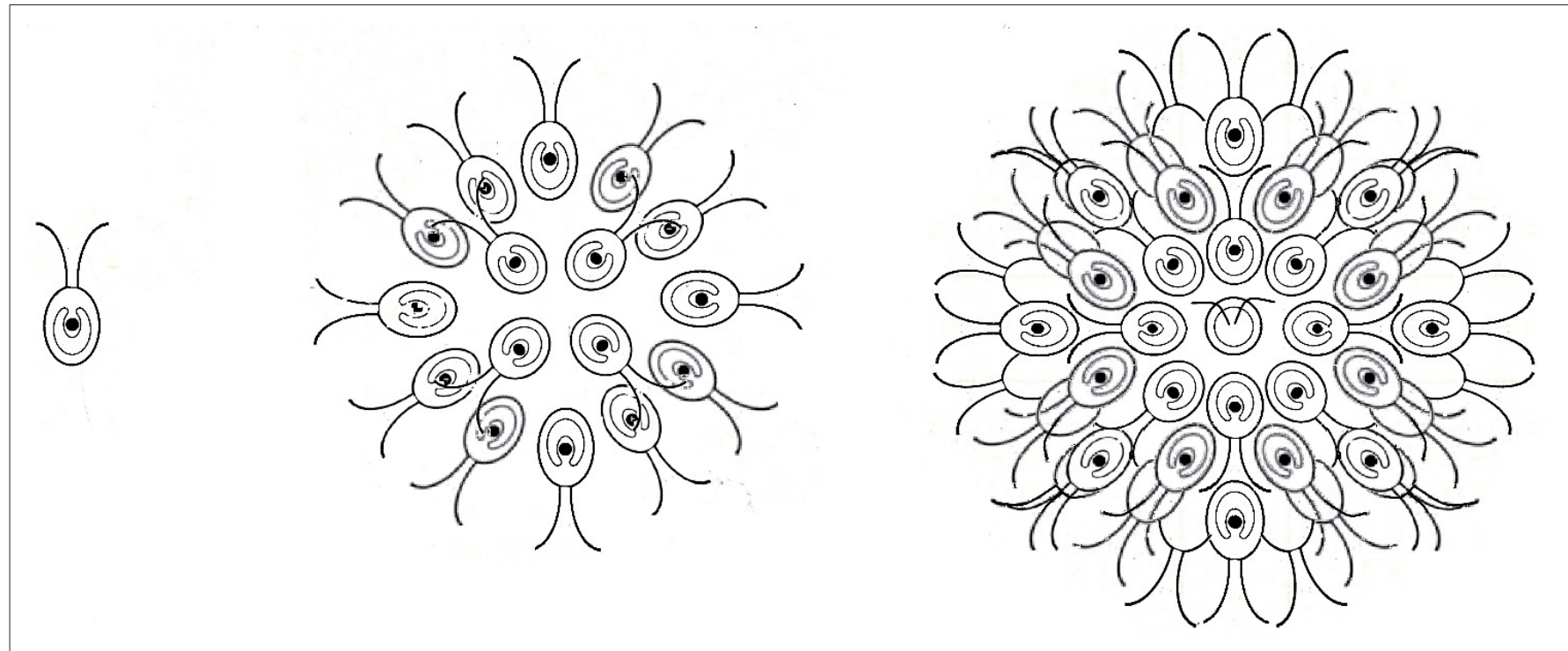

FIGURE 1: Chlamydomonas (left), Gonium consists of a flat disk of cells (middle) and Eudorina consists of a sphere of cells (right).

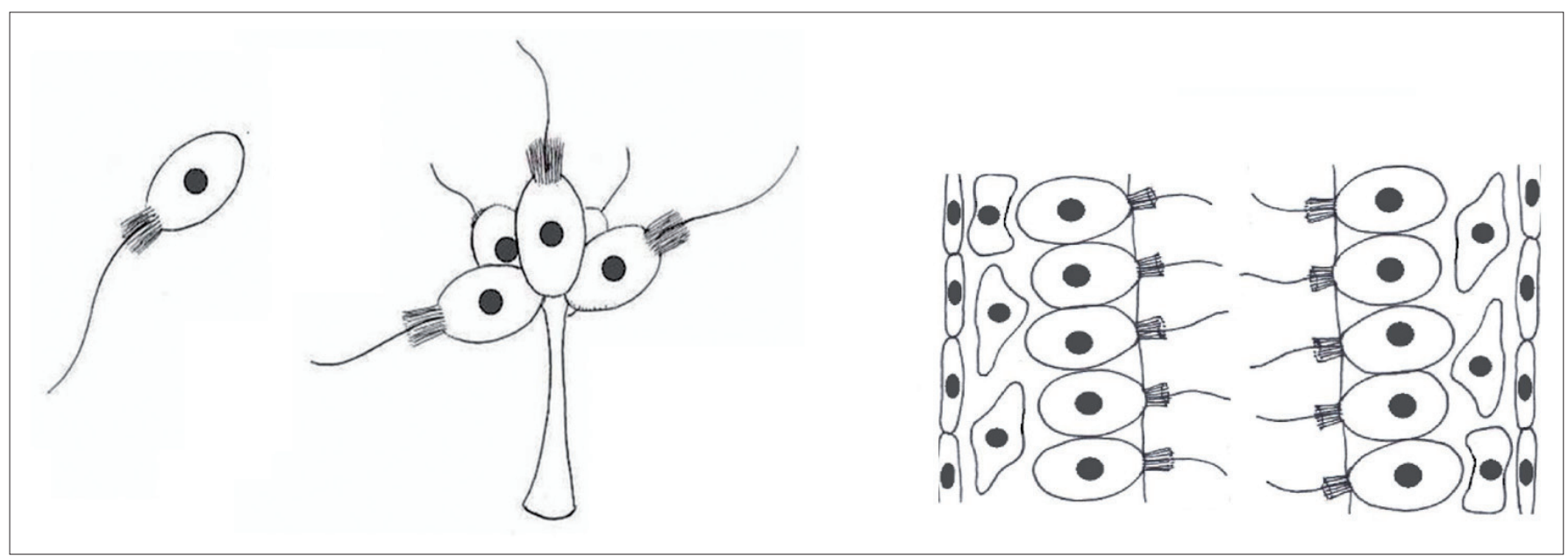

FIGURE 2: Single choanoflagellate protist (left) and Proterospongia consisting of a colony of a few chonoflagellates (middle) and a section through a sponge (right). 


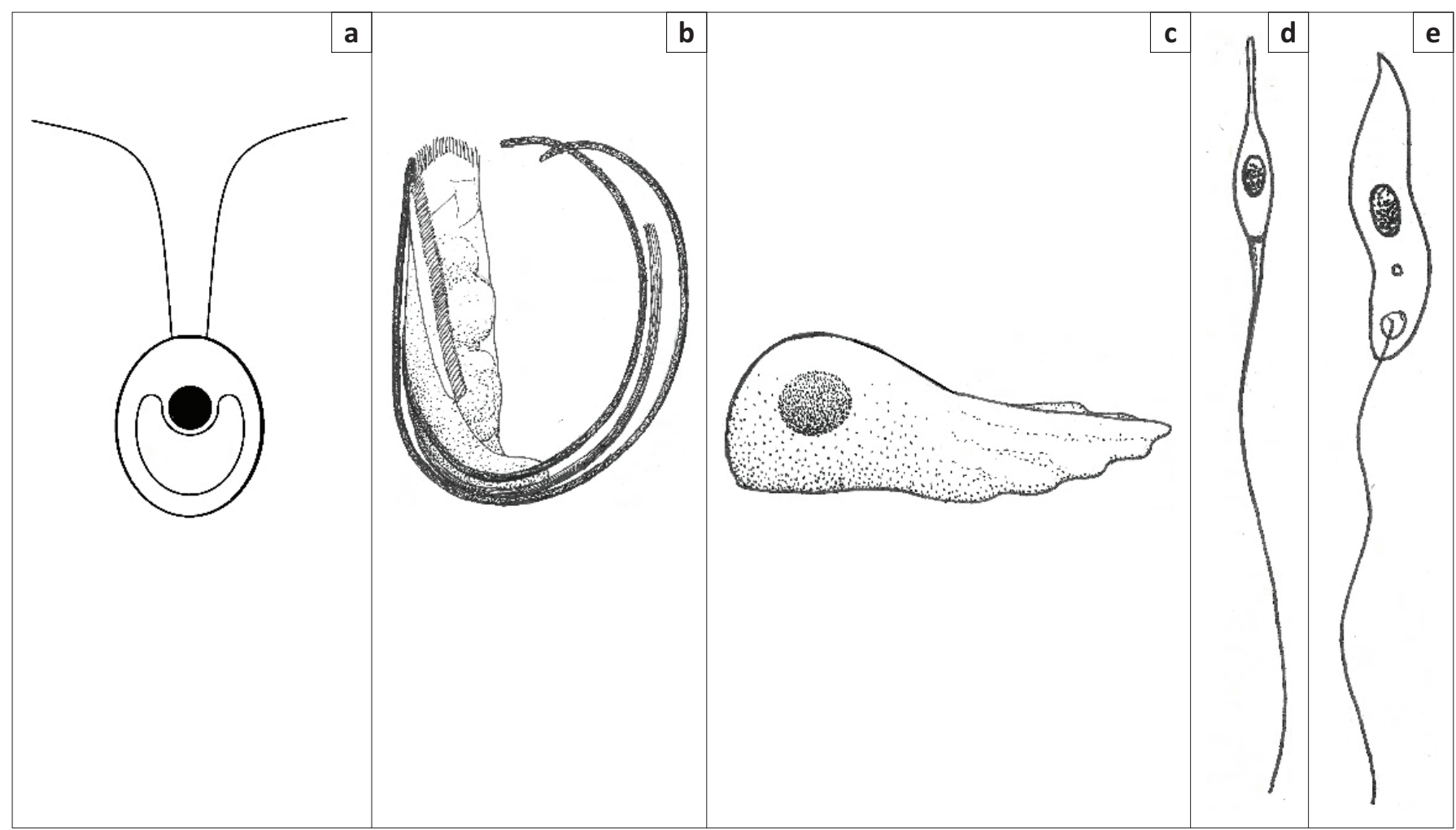

FIGURE 3: (a) Zoogamete (sperm or egg) of algae. (b) Sperm of a clubmoss. (c) Ameboid sperm of a nematode. (d) Sperm of a butterfly. (e) The protist Leishmania.

protist species can change from one form to the other, then it seems to be a logical alternative for the flagellated sperm.

Sperm and egg cells develop from primordial germ cells which represent the ancestors of the germline. These germ cells are diploid like other somatic cells but with the difference that germ cells do not have a specific function like somatic cells which form tissues and organs. The function of the germ cell is to produce a whole new organism. It has been shown that stem cells can transform into germ cells and back again (Conti \& Giudice 2008). The germ cells can be seen as 'transgenerational stem cells' (Pelosi, Forabosco \& Schlessinger 2011). In the process of transformation from germ cells to sperm and egg cells, they undergo a halving of their genetic component in preparation of the possible fusion with a cell of the opposite sex.

If the germ cell is capable of forming a whole individual, what is the role of the other millions of somatic cells other than supporting the germ cells? The germ cells are in fact not part of the embryo but are originally located in the ectoderm outside the embryo as separate cells that have no somatic function. In the third week (in humans), the germ cells, which resemble amoebas, begin to migrate from the ectoderm into the yolk sac wall and cluster near the exit of the allantois. The germ cells enter the embryo between the fourth and sixth week of embryonic development when they crawl along the yolk sac wall to the vitelline and from there into the wall of the hindgut. From there they continue to move along the dorsal mesentery connecting the gut to the mesonefros and from there they invade the gonadal ridge which they then colonise (see Figure 4).

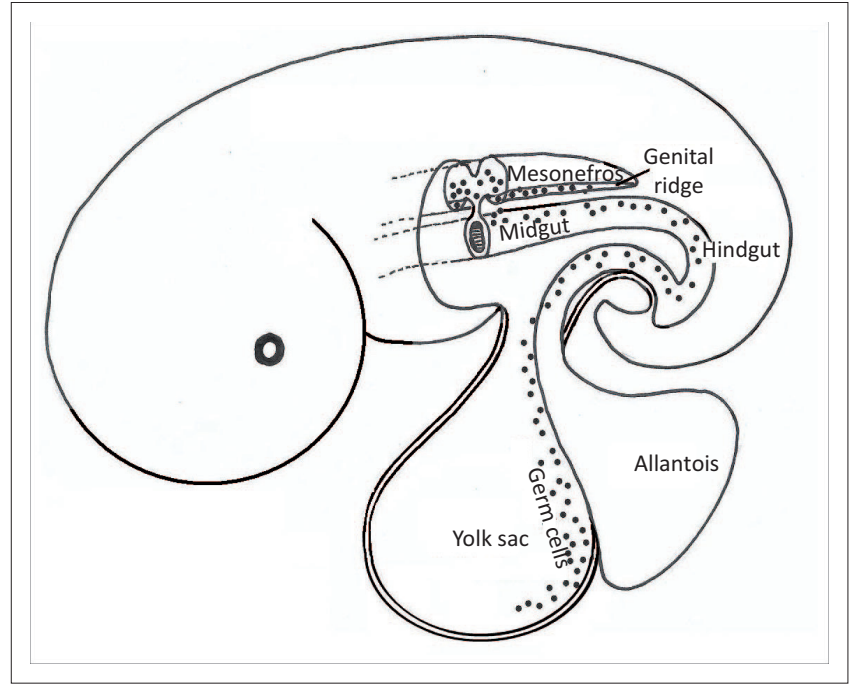

FIGURE 4: The migratory route of the primordial germ cells.

The implications of this phenomenon are profound primordial germ cells are not part of the body of the embryo because they originate outside the embryo. Germ cells are not produced by the gonads (testes and ovaries) either but only invade them after these organs have developed. The germ cells start to multiply through binary fission like protists do during the migration and continue to do so inside the gonads. Each of these thousands of amoeba-like cells has the potential to produce a whole new organism (Twyman 2001).

The germ cells form during the cleavage of the cells that produce the embryo, but while the somatic cells form as part of organ systems where they will perform certain functions, 
the germ cells remain undifferentiated clones of the original zygote until they give rise to the sperm and eggs. Germ cells are immortal while somatic cells are mortal. The body is merely the carrier of the germ cells and is discarded between generations of germ cells begetting germ cells. Of course, thousands of germ cells die, but life is a continuous genetic stream connecting one generation of germ cells to the next (Cinalli, Rangan \& Lehmann 2008).

When people look at nature, they assume that the tree, moss, sponge, jellyfish, mayfly or human is the actual organism that reproduces, has an ecological function and is the final product of evolution. This assumption ignores the fact that the cell is the actual organism that reproduces and that the tree, moss, sponge, jellyfish, mayfly or human is merely the vehicle carrying the germ cells and is used like a golem to access resources for these cells, defend them and which creates conditions for them to reproduce.

Ultimately there is no higher purpose or reason for existence but to exist. The ways in which molecules are acquired by organisms, where over $80 \%$ of the species are parasites, exclude the possibility of morality or higher purpose in nature (Durand 2016). The process of mating is equally mindless and horrifying in many cases. The body - regardless of its beauty and intricacy and complexity and intelligence is merely the carrier of the germ cells. These cells force many organisms to engage in behaviour which is dangerous and in many cases fatal for one reason only - to reproduce.

If reproduction is the ultimate reason for the existence of life, then mating is the main reason for the existence of the multicellular organism. All the excessive behaviour of animals such as singing, croaking, displaying, building nests, scent marking, fighting and killing opponents is in order to find a mate. Many species of birds display by having brightly coloured plumage, long tails and they sing in order to attract a mate. But these characteristics also attract predators and many of these males are killed and eaten for their pains. The species' existence depends on the males being polygamous and in so doing they fill the breach left by their dead brothers.

There are thousands of examples in nature where organisms just exist for as long as it is necessary to procreate after which they die (Cole 1954). In spiders and praying mantises, the male is customarily eaten by the female after mating. The Dark fishing spider male dies automatically after he transfers his sperm to the female. In others, the female grabs the male and consumes him after copulation. In the case of the praying mantises, the female eats the male while he is copulating with her. During copulation, the male bee's genitals distend explosively into the female's genital opening with the result that his genitals are torn from his body after which he falls lifelessly to the ground. The female bee can copulate with several males one after the other on her maiden flight. She stores the sperm in a sperm chamber in her body where they will be housed and fed for the duration of her life which may be several years (Collins et al. 2006).
Octopi males have a hectocotylus which is a modified tentacle carrying the penis and testes. The male introduces the hectocotylus into the female's genital opening to fertilise her eggs. In some species, the female rips off the hectocotylus and shoves it into her genital opening. In other species, the male voluntarily rips off the hectocotylus and releases it whereupon the hectocotylus swims by itself through the sea in search of a female. In all cases, the male bleeds to death being mortally wounded. The female will guard over her eggs after she has laid them without once abandoning them even to eat. She dies when they hatch (Nixon \& Young 2003).

In most animal species, the only reason why males exist is to impregnate the female. This is why the males of so many females die after mating. In the case of the angler fish, the larval male fish swims off in search of a female as soon as it has hatched. When it finds a female, he attaches himself to the female. Her skin exudes enzymes which dissolve the skin of his mouth. The male's flesh fuses to that of the female. His digestive system, nervous system, respiratory system and circulatory system degenerate afterwards and he becomes completely dependent on the female. Except for his testes, the body atrophies and he becomes a body part of the female for the rest of her existence. Her hormones trigger the release of sperm from the males attached to her to coincide with the release of her eggs (Pietsch 2005).

In other marine animals such as the spoonworm and Sacculina, the male is taken into the body of the female where it remains with the sole purpose of fertilising her eggs. These males also atrophy to little more than testes as they spend the rest of their lives like endoparasites inside the female (Barnes 1982; Zimmer 2000).

Thousands of species of animals, such as mayflies, silk worms, clothes moths and salmon, have adults that do not feed. In these species, the male and female adults die as soon as the males have released their sperm and the females have laid their eggs. There is no reason after reproduction for them to continue to live. The same wastefulness can be seen in plants such as the billions of flowers of Namaqualand. These hundreds of square kilometres of flowers are reproductive organs all vying for the attention of fertilisers. The germ cells survive in the billions of seeds left in the dirt after the plants have died, lying in wait for the next season to repeat the process.

The redundancy of the adult organism after reproduction is well illustrated in the case of Adactylidium mites where the adult female has no genital opening and no adult males exist. One male larva and four female larvae develop inside the adult female's body. The male larva copulates with and impregnates his sister larvae. They continue to feed, grow, molt and defecate inside their mother. When they are big enough, the young females eat their way through their mother's living body and rip her open. They leave their dying mother which is now little more than a torn bag of faeces and exoskeletons. Their unborn brother, who is unequipped to survive outside the mother, dies almost instantly (Gould 1980). 
The germ cells are obviously not aware of all of this, but like any efficient parasite, they survive in the bodies of the living continuing the carnage generation after generation. The success of the species depends solely on its ability to reproduce. Ultimately the success of an organism - regardless of its size, beauty, intricacy or intelligence is reduced to the success of a single amoeba-like cell. The germ cell determines the morphology and behaviour of the organism that carries it and is ultimately responsible for the horns, teeth, claws, jaws, stings and poisons of its host and the violence and death meted out by the host organism to those around it. The germ cell is the driver behind natural selection where only the fittest will survive in this world of pain and death which it created.

The germ cells exist in relation to others by means of which they can feed on and reproduce with while their carriers are sacrificed when they have done so. One of the prerequisites of life is that they can only survive if they can change and adapt to the constantly changing conditions on earth. These changing conditions include not only changes in climate but also changes in the organisms they have to live off, escape from and mate with. What sexual reproduction and evolution show is that organisms give rise to different organisms which means that it is a system in which allopoiesis occurs as organisms give rise to progeny different from themselves. In other words, an open tree-like system is created in biology instead of the maintenance of a linear system.

Evolution of each species is driven by its own strain of germ cell which is only concerned with replication. The diversification of species over time is caused by the fact that the organisms which act as the carriers of the germ cells have to adapt constantly to an ever-changing ecology in order to survive. It is important to realise that while the bodies of organisms, which act as the carriers of the germ cells, undergo profound transformation over millions of years, the germ cells remain morphologically, physiologically and behaviourally relatively unchanged. These evolutionary changes are however encoded within the ever-changing genetics of the germ cell which means that replication is not stable or unchanging as the theory of autopoiesis assumes.

If understood in its original definition that the cell reproduces itself and only itself (Zeleny 1981), then there are many instances of autopoiesis in nature - but these fall outside the definition of evolution which implies that constant change occurs as organisms adapt to their constantly changing environment. We are sometimes blinded by the spectacular show of evolution to appreciate the fate of all species that ever existed, namely, that they all go extinct the moment they fail to change enough to adapt to the changing environment and in failing to change lose the evolutionary race (Van Valen 1973). Of course, not all organisms that do change will be selected but only those with the appropriate characteristics necessary for survival.

\section{Conclusion}

The internal organisation of a cell, organism or society becomes just part of much more intricate processes, which involve origin, evolution, selection and ecology. Life can be defined as the flow of energy through organic molecules that have acquired the ability to make replicas of themselves, albeit slightly different ones, by means of that energy. If the question is asked: What is life? Then the view that life is a part of a hierarchy of related but ever-changing organisms that continues through time on a temporal axis and that it acts as a conduit for biological energy (either as source or consumer) on the spatial axis would fit the definition of life better than the view that it consists of a closed system which relates only to itself. Every cell or organism relates genetically to ancestors before them and descendants after them and ecologically to things around them on which they feed or are feeding on them. Allopoiesis rather than autopoiesis fits the description of life as a function where these two natural forces - genetic inheritance with continuous modification and the flow of molecules and energy through an everchanging ecology because it implies that life is open on the temporary and spatial dimensions.

In my opinion Maturana and Varela made a basic mistake in their interpretation of the real world which inspired their theory of autopoiesis. While it is true that cells in general do make copies of themselves, they merely express the genetic code received from the germ cell under the impact of environmental forces which may allow or suppress the expression of the genetic code and in some cases, cause it to mutate. While the somatic cells in the mulicellular sphere die, the germ cells, like the protists from which they stemmed, and the bacteria and archaea before them, continue as part of the immortal evolutionary tree from which all living things, including humans, spring.

Nature surges forward relentlessly and amorally because it can and must or it would not have been here. If the purpose of life is to beget life, then everything else is irrelevant. We are compelled by these germ cells to engage in life-threatening and irrational activities in their attempt to unify with others or consume others - this behaviour includes jealousy, murder, competition and wars. Germ cells have to persevere regardless of the cost to others - even its carriers. The purpose and outcomes of existence are determined by these ameboid cells living inside our bodies.

\section{Epilogue}

I'm sane now, free and clear-minded, without the dark shadows of ignorance the detestable books of chivalry shrouded over me, owing to my bitter and continual reading of them. I now see their foolishness and their deceits, and my only grief is that this realization has come to me so late that it doesn't allow me time to compensate by reading other books that could be the light of my soul

Señor Alonso Quixana (Don Quixote). (De Cervantes 1615)

\section{Acknowledgements}

I would like to thank Cornel du Toit and Jacques Kriel for long discussions and their suggestions and positive criticism of this article. 


\section{Competing interests}

The author declares that he has no financial or personal relationships which may have inappropriately influenced him in writing this article.

\section{References}

Bača, M., Schatten, M. \& Deranja, D., 2007, 'Autopoietic information systems in modern organizations, Organizacija', Journal of Management, Informatics and Human Resources 40(3), 157-165.

Barnes, R.D., 1982, Invertebrate zoology, Holt-Saunders International, Philadelphia, PA, pp. 870-873.

Cinalli, R.M., Rangan, P. \& Lehmann, R., 2008, 'Germ cells are forever', Cell 132, 559562. https://doi.org/10.1016/j.cell.2008.02.003

Cole, L.C., 1954, 'The population consequences of life history phenomena', The Quarterly Review of Biology 29(2), 103-137. https://doi.org/10.1086/400074

Collins, A.M., Caperna, T.J., Williams, V., Garrett, W.M. \& Evans, J.D., 2006, 'Proteomic analyses of male contributions to honey bee sperm storage and mating', Insect Molecular Biology 15(5), 541-549. https://doi.org/10.1111/j.1365-2583.2006. 00674.x

Conti, M. \& Giudice, L., 2008, 'From stem cells to germ cells and back again', Nature Medicine 14, 1188-1190. https://doi.org/10.1038/nm1108-1188

De Cervantes, M., 1615, 'The ingenious knight Don Quixote de la Mancha, Part II, Chapter 74', in E. Urbina (ed.), Electronic variorum edition of the Quixote Cervantes Project, Texas A\&M University, viewed 22 February 2017, from http:// cervantes.tamu.edu/V2/CPI/variorum/index.htm

Dougall, C., 1999, 'Autopoiesis and Aristotle: Rethinking organisation as form', Kybernetes 28(6/7), 777-791. https://doi.org/10.1108/03684929910283196

Dougall, C., 2000, 'Reconstructing Maturana - Metaphysics and method', Kybernetes 29(4), 491-498. https://doi.org/10.1108/03684920010322235

Durand, J.F., 2013, 'Emergence as cornerstone in understanding evolution: Examples from Zoology', South African Science and Religion Forum Conference Papers Chance, Causality, Emergence: Interdisciplinary Perspectives, pp. 67-101. Research Institute for Theology and Religion, UNISA, Pretoria.

Durand, J.F., 2016, 'Nature, creation and morality: The case of parasites', HTS Theological Studies 72(4). https://doi.org/10.4102/hts.v72i4.3841

Fleischacker, G., 1988, 'Autopoiesis: The status of its system logic', Biosystems 22 37-49. https://doi.org/10.1016/0303-2647(88)90048-2

Gould, S.J., 1980, 'Death before birth, or a mite's nunc dimittis', in The Panda's Thumb: More reflections in natural history, pp. 69-75, W.W. Norton \& Company, New York.

King, M., 1993, 'The "truth" about autopoiesis', Journal of Law and Society 20(5), 218-236. https://doi.org/10.2307/1410168
King, N., 2004, 'The unicellular ancestry review of animal development' Developmental Cell 7, 313-325. https://doi.org/10.1016/j.devcel.2004.08.010

Luhmann, N., 2003, 'Organization', in T. Bakken \& T. Hernes (eds.), Autopoietic organization theory drawing on Niklas Luhmann's social systems perspective, pp. 31-52, Abstract, Liber, Copenhagen Business School Press, Oslo.

Luisi, P.L., 2003, 'Autopoiesis: A review and a reappraisal', Naturwissenschaften 90, $49-59$.

Maturana, H.R., 1975, 'The organisation of the living: A theory of the living organisation', International Journal of Man-Machine Studies 7, 313-332. https:// doi.org/10.1016/S0020-7373(75)80015-0

Maturana, H.R., 1987, 'The biological foundations of self-consciousness and the physical domain of existence', in E. Caianiello (ed.), Physics of cognitive processes, pp. 324-379, World Scientific, Singapore.

Maturana, H.R. \& Varela, F.J., 1973, 'Autopoiesis: The organization of the living', in H.R. Maturana \& F.J. Varela (eds.), Autopoiesis and cognition, pp. 59-138, Reidel, Boston, MA.

Maturana, H.R. \& Varela, F.J., 1980, 'Autopoiesis and cognition: The realization of the living', Boston Studies in the Philosophy of Science 42, $141 \mathrm{pp}$. https://doi. org/10.1007/978-94-009-8947-4

Mingers, J., 1995, Self-producing systems: Implications and applications of autopoiesis, Plenum, London. https://doi.org/10.1007/978-1-4899-1022-6

Nixon, M. \& Young, J.Z., 2003, The brains and lives of Cephalopods, Oxford University Press, Oxford, UK, $408 \mathrm{pp}$

Pelosi, E., Forabosco, A. \& Schlessinger, D., 2011, 'Germ cell formation from embryonic stem cells and the use of somatic cell nuclei in oocytes', Annals of the New York Academy of Science 1221(1), 18-26. https://doi.org/10.1111/j.1749-6632.2011. 05982.x

Pietsch, T.W., 2005, 'Dimorphism, parasitism, and sex revisited: Modes of reproduction among deep-sea ceratioid anglerfishes (Teleostei: Lophiiformes)' Ichthyological Research 52(3), 207-236. https://doi.org/10.1007/s10228-0050286-2

Twyman, R.M., 2001, Developmental biology, Bios Scientific Publishers, Oxford, $451 \mathrm{pp}$.

Van Valen, L., 1973, 'A new evolutionary law', Evolutionary Theory 1, 1-30.

Varela, F.G., Maturana, H.R. \& Uribe, R., 1974, 'Autopoiesis: The organization of living systems, its characterization and a model', Biosystems 5, 187-196. https://doi. org/10.1016/0303-2647(74)90031-8

Von Glaserfeld, E., 1990, Teleology and the concepts of causation, Philosophica 46 (2), 17-43.

Zeleny, M., 1977, 'Self-organization of living systems: A formal model of autopoiesis', International Journal of General Systems 4(1), 13-28.

Zeleny, M., 1981, 'What is autopoiesis?', in M. Zeleny (ed.), Autopoiesis: A theory of living organization, pp. 4-17, Elsevier North Holland, New York, viewed 01 May 2017, from http://cepa.info/1194

Zimmer, C., 2000, Parasite Rex: Inside the bizarre world of nature's most dangerous creatures, Atria Books, Simon \& Schuster Publishing, New York, 320 pp. 